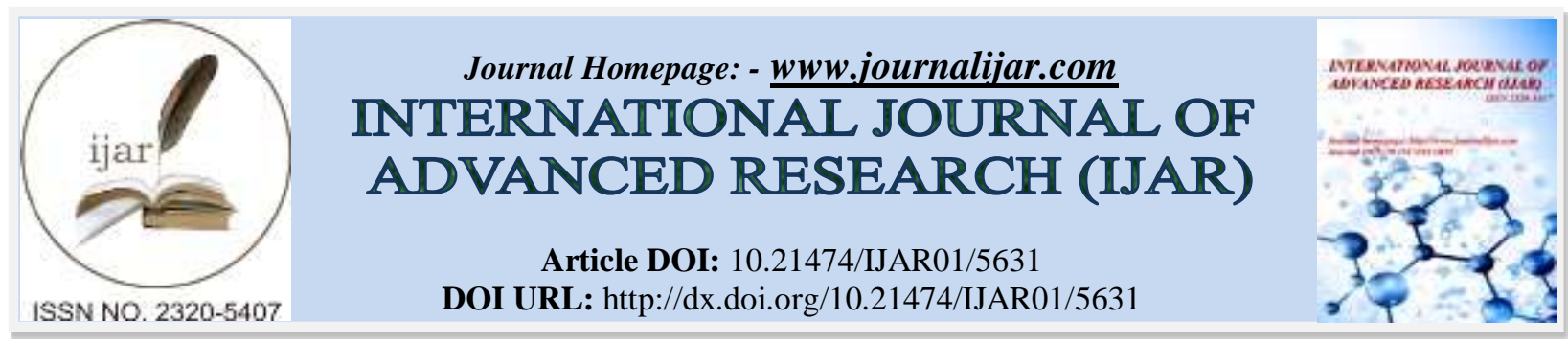

RESEARCH ARTICLE

\title{
BACHELOR STUDENTS' PERCEPTION OF THE TECHNOLOGY AND INFORMATION MANAGEMENT COURSE.
}

\author{
Laura Cristina Piñón Howlet, Alma Lilia Sapién Aguilar, María Del Carmen Gutiérrez Diez and Mario \\ Carrera Ramos. \\ Universidad Autónoma de Chihuahua.
}

\section{Manuscript Info}

Manuscript History

Received: 15 August 2017

Final Accepted: 17 September 2017

Published: October 2017

Key words:-

Program content, educational modalities, educational processes, information and communication technologies, course evaluation.

\begin{abstract}
The objective of the research was to analyze bachelor students' perception of the Technologies and Information Management course at the Autonomous University of Chihuahua. The study was conducted during the period 2014-2015. This was an empirical study with a nonexperimental, descriptive quantitative approach. The total sample consisted of 366 students attending their first semester in face-to-face, blended and virtual modalities. The instrument used was a questionnaire, which was applied to the students in their classrooms. A regression analysis of the main variables was conducted. There are several aspects that need to be changed in order to make the subject more interactive and innovative, in accordance with current needs. A program restructure of the subject is proposed, one where the central axes are the powers of information and communication technologies necessary for meaningful learning, and consistent with each professional's chosen area of expertise. It's also necessary to train teachers both technologically and pedagogically, as well as to upgrade computer equipment. It was concluded that most students considered the subject good, and there is a good command of information and communications technologies by students.
\end{abstract}

Copy Right, IJAR, 2017,. All rights reserved.

\section{Introduction:-}

UNESCO (1998) stated that: "the rapid progress of information and communication technologies are changing the development, acquisition and transmission of knowledge.". New scenarios are opening up, where technologies improve the way we produce, organize, disseminate, check, and access knowledge, as a result, education faces a major challenge to ensure equitable access to these technologies at all educational levels (Castro et al., 2007). For this reason, higher education at a global level, has had to innovate and evolve in response to the economic and social changes brought about by globalization. This reality leads to the need to improve quality, as well as to confront successfully the educational competitiveness. It is clear that educational processes, at present, are more complex and dynamic, so that the methods traditionally used, are not sufficient for proper planning and management in this changing world. Higher education, therefore, needs to adapt to the new and dynamic environment that surrounds it, one in which the future is characterized by new challenges (Rodríguez et al., 2014). 
The inclusion of information and communications technologies (ICT) in education has generated new educational schemes and other ideals, which have been formulated by teachers, psychologists and epistemologists. Such ideals are: 1) offer the student a learning environment rich in materials and experiences that capture their interest; 2) give greater freedom to explore, observe, analyze and build knowledge; 3) stimulate imagination, creativity and critical thinking; 4) provide multiple sources of more robust and up-to-date information and; 5) allow for multi-sensory learning experiences (Campo et al., 2013). At present, the Technologies and Information Management subject (TyMI, for its acronym in Spanish) is taught in educational programs at undergraduate level in all the faculties of the Autonomous University of Chihuahua (UACH, for its acronym in Spanish). This course is offered in face-to-face, blended, and virtual modalities, with enrollment ranging between 5.000 and 6.000 students.

In the university 2011-2021 development plan for UACH's educational model, the mission states that: "We perform our task of educating upstanding people with universal values, and capable of providing relevant and creative responses to a changing world, as well as generating, implementing, disseminating and transferring knowledge, as well as developing technologies.". At the same time, this educational institution establishes within its values and principles: "the responsibility in the formation, generation and innovative application of knowledge in the framework of ongoing processes of continuous improvement and quality assurance.". Therefore, considering this institutional philosophy of the UACH, the new design of the TyMI course has as its main purpose to develop technological and communication skills in the uniersity student, which will help improve the learning process and strengthen its graduate profile.

In the last eight years, the TyMI course program in the UACH hasn't had updates, despite the fact that it's taught in 15 academic units. It is well known that students do not have an interest in the course, have deficiencies in the use of advanced office automation, and lack the ability to make excellent professional presentations and projects. All these indicators have shown that the program does not cover the most essential needs of the university student and, at the same time, reflects the need to build a new TyMI program design.

It is important to mention that the authorities of the UACH followed up views expressed by the course teachers. From that exercise, came an agreement to develop a proposal which aimed to detect the perception of students enrolled on the TyMI course. The new course program is expected to be designed taking into account the results from our current research, all the while aiming to strengthen the professional development of the university student, according to the graduate profile set by the institutional vision.

The purpose of the current investigation was to analyze the perception of students enrolled on the Technologies and Information Management (TyMI) course offered in the Autonomous University of Chihuahua (UACH). The specific objectives arising from this general objective were: 1) to detect if the course has the characteristics necessary for the education of the university students; 2) to evaluate the content of the three study objects taught in the TyMI course; 3) to diagnose the students' perception of evaluation activities; 4) assess the support provided by teachers to students during the training process; and 5) identify the opinion of students on the organization of the TyMI course.

It is clear that, at present, there is a dynamic spread of technological resources that are demanding, in consequence, changes in the educational context. In other words, there is a technological expansion that by means of various electronic devices, is generating changes in society, including education. For the universities in general, and in particular for the $\mathrm{UACH}$, it is of vital importance that the competencies educational processes are not diverted from the purposes set forth in its mission and vision. That is to say, to educate considering the comprehensive training of university students, as well as their professional profile.

In addition, it is essential that their education and training remain in accordance to the standards of world class quality to facilitate, as a result, labor mobility and success in their professional performance. For this reason, facing prospects and global trends, the constant monitoring of academic units in order to assist them with continuous improvement programs, and if necessary, a refocus of the objectives and educational purposes that are set out in the educational model, prove to be a real need. As a result, the educational institution will be able to focus on ensuring the quality of its teaching and learning processes.

\section{Theoretical Approach:-}

Marin (2006) specified that the UACH's educational model is based on three fundamental axes: competency-based education, curricular flexibility, and educational processes focused on learning. The above as a whole, calls for the 
development of educational practices oriented toward interdisciplinary practices, group work, knowledge applied to concrete realities, the role of the teacher as a coordinator and learning facilitator, and the student's active participation. In this context, the concept of competence is not limited only to a cognitive level, as this would lead to the isolation of social relationships; it goes beyond that and incorporates the perspective of attitudinal and procedural aspects.

\section{Competency-Based Education:-}

In the UACH's educational model, in particular, it is conceived that a competence must have the following properties: be focused on relevant performances, have balance and be comprehensive within basic learning, foster unit construction, be a point of convergence, and promote higher levels of individual autonomy. On the other hand, skills are classified as: basic, professional, and specific. The basic competencies are those whose development provides identity to all graduates, no matter their educational program, and are used to referrer to the qualities of said graduates. Teamwork and leadership, problem solving abilities, communication, entrepreneurship, and the socio-cultural aspect are all part of this competence. For example, the TyMI course that is programed at UACH considers the following competencies: team work, interaction between teams, communal sharing of knowledge, experiences, and lessons learned on ICT. With regards to communication, the student will use the information technology services offered by the UACH and manage applications for the presentation of their work, providing audiovisual support during thematic explanations. In the socio-cultural section, the participant will discuss and argue about current issues of ICT, in relation to social, cultural, scientific or sustainable development issues. Finally, in the Troubleshooting section, arguments in favor and against real ICT problems will be presented, with conclusions, recommendations or solutions based on their arguments.

At present, UACH uses WebEx for the virtual modality, as well as Moodle for the same modality and as face-to-face classroom support. Moodle is a learning platform designed to provide educators, administrators, and students a single integrated system, robust and secure, to create personalized learning environments.

In other words, it is a project in development, designed to support a constructive social education framework (Moodle, 2015). With regard to WebEx, Cisco Systems, it's a tool that allows instant communication with distant people in the same city or even in different parts of the world. A strength of this tool, is that it allows you to share documents and presentations, display products and services, and collaborate as a team.

A comparative advantage is that you can immediately start a safe web meeting from your desk. The implementation of this new distance education scheme through the WebEx tool, allows students to access an educational first world tool from anywhere with Internet access.

\section{Materials and Methods:-}

The present work is an empirical study with a quantitative approach, not experimental, and descriptive, which was based on a survey conducted in the year 2014. The total population consisted of 7.733 first to third semester students assigned to the $15 \mathrm{UACH}$ faculties. The information on the total number of students was provided by the institution's academic office, where the sample was taken from. A stratified random sampling method was used, distributed in proportion with an error of 5\% and a 95\% confidence level. A total sample of 366 students in face-toface, blended, and virtual modalities, was obtained. The instrument used was a questionnaire, which was developed with a total of 48 closed questions and two open ones, which requested an agreement or disagreement assessment according to the Likert scale.

In specific terms, each question in the questionnaire presented the following categories: very poor, poor, fair, good, and very good. The total number of questions was grouped to evaluate five indicators or operational variables: 1) Training, which would establish if the learning activities had a clear objective, and specific methodology with structure and sequence; 2) Content, which pondered its usefulness, level of difficulty, and whether they were of interest; 3) Evaluation Activities, to determine their difficulty and utility, and whether they received feedback from the teacher; 4) Support, to know if teachers provided support during the training process; and 5) Organization, to identify if they used the tools and communication spaces provided by the university during the training process, as well as to evaluate if they had difficulty gaining access to the platform, navigating it, and downloading digital materials quickly. 
For the statistical analysis of the information, descriptive statistics was used, and furthermore, there was a correlation and regression analysis. For the regression analysis, the dependent variable was the degree of satisfaction of the TyMI course.

The independent variables were the following; $\mathrm{X} 1=$ which identified the characteristics of the course and took values from 1 (very poor) to 5 (very good); X2= which pondered on the contents of the course from level 1 (very poor) to 5 (very good); X3 = which identified the evaluation and management values from 1 (very low) to 5 (very high); X4= which assessed the level of support identifying values from 1 (very poor) to 5 (very good); X5= which pondered communication and was assessed from level 1 (never) to 5 (systematically); and X6= which evaluated difficulties with values ranging from 1 (very low) to 5 (very high).

\section{Results:- \\ Training Variable:-}

In the results of the Training variable, it was found that the TyMI course was regarded as acceptable. This result indicates that more detailed work is required in the course, since it is far from the ideal rating of very good. There wasn't a big difference between the opinions of students from the different modalities; however, it is striking that distance learning students were the ones who consistently evaluated the course's traits with a lower value. The interaction with the teacher in the forums was one of the traits evaluated by the distance learning students with the lowest score. An investigation conducted by Garcia and Pineda (2010) at the National Autonomous University of Mexico, points out the importance of instructional design in the collaborative activities in virtual discussion forums, as it has an effect on the extent and quality of discursive interactions and on the construction of knowledge. Therefore, it is necessary to review the characteristics of the learning tasks, to ensure your design uses the interaction and discourse resources that can be generated among students.

\section{Content Variable:-}

To identify the results of the content variable, the following objects of study were defined, and will later on be described: 1. ICT Education, 2. Information Education, and 3. Media Education. For the object of study 1, ICT Education, the lessons included information technologies and communication technologies panorama.

The students of the face-to-face and blended modality considered that they often used the three education lessons, but not the students of the virtual mode, who indicated that the most used one was communication technologies.

According to students in face-to-face and blended learning modalities, the most liked lesson from Object 1, and the one with the most current content, was the information technologies one, while those of the virtual mode specified that the three lessons were equally relevant and liked. Nothing was detected about the difficulty of the contents. The lesson that was less interesting for the students on distance learning, was the ICTS panorama, while for the rest of the students on the other modalities, all lessons were considered interesting. The students in the face-to-face and blended modality specified that with the information technologies lesson they learned more, while students in virtual modality pointed out that they learned with all three lessons.

The students in virtual modalities reasoned that the three lessons were useful for application in real life, while blended learning course students thought that the communication technologies lesson was better. According to Diaz (2010), the training of teachers in the field of ICT, in order to use appropriate instructional strategies, allows the courses to be used in a practical and efficient manner by the students in higher education.

In the object of study 2, Information Education, the lessons covered were: informational needs or problems, search and evaluation of information sources, and information analysis. All students stated that they used the three lessons with frequency.

Students in the face-to-face and blended modality specified that search and evaluation of information sources was the lesson they liked most, due to its relevant content, while students in virtual modality stated that the three lessons were currently relevant. On the difficulty in the contents, there was no opinion. All of the students considered Object 2 lessons to be interesting, and of no difficulty. The face-to-face and blended learning modality students specified that they learned more with the lesson of search and evaluation of information sources, while students of the virtual modality pointed out that they learned with the three lessons. 
The students of the face-to-face and blended modality stated that the topic of search and evaluation of information sources was useful for real life applications, while virtual students indicated that the three lessons were of interest. However, there are students who mentioned that the topic of information quest should be strengthened, since this knowledge and the tools that go along with it, were useful for other subjects.

In particular, students expressed the view that teachers should be trained in database management, since not all of them know how to use them. This result is consistent with an investigation by Espinoza, et al. (2006) in a Venezuelan university which concluded that the professors were unaware of the ideal tools for scientifically reliable information. For this reason, the quality of the documentation taken as basis for upgrade and future research was questioned.

When it comes to the contents of the object of study 3, Media Education, all of the students felt that the three lessons they learned were frequently used. Regarding the current relevancy of the contents, the total number of students expressed the view that the three lessons comply with that feature.

The most accepted lesson by face-to-face and virtual modality students was digital newspapers; for blended modality students that lesson was critical thinking, and all of the students found the three lessons to be of their liking.

All of the students stated that they observed no difficulty in the contents, and considered Object 3 contents to be interesting. The face-to-face and virtual modality students specified that they learned with the three lessons, while the distance learning students indicated that they learned more with the critical thinking lesson. All of the students described that the three lessons of Object 3 were useful for real life applications.

An interesting aspect to highlight in these results, is that virtual modality students are more satisfied with the content and learning activities. In accordance with Olivares and Heredia (2012), current and prospective students need to be trained with teaching techniques that allow them to develop skills which would enable them to make pertinent decisions regarding what to learn and use through their personal and professional lives.

\section{Activities Variable:-}

Regarding the degree of difficulty of the evaluation tasks or activities, the students of the three modalities cataloged them as acceptable, without a high level of difficulty. The students commented that the tasks and activities carried out in the course had been useful. In the same way, the feedback at the end of the integration and evaluation activities ranged from acceptable to highly valuable.

It is of paramount importance that there should be a timely feedback, because it's information provided by a teacher regarding student performance aspects, or the student's understanding of a task. An investigation carried out by Hattie and Timperley (2007) concludes that feedback to students may increase effort, motivation, and allows to reduce discrepancies in order to better understand the tasks to be performed. Feedback is one of the most important influences on student learning. An important objective of the educational process is to help identify: 'How will I?' 'Where am I going?' questions, and provide remedies with alternatives 'And now?'. In relation to the TyMI course tasks and activities, there are students who noted that they should be innovative, interactive and fun.

These results are consistent with an investigation by Huett and Kaulich (2015) where student feedback about some course materials, suggest that readings be more interactive than just reading presentation slides. They also stated that teachers must pause to interact with students, asking questions or comments, in addition to the recommended use of practical sessions during the course, relevant to the students' interests and needs as future professionals.

\section{Support Variable:-}

The students considered acceptable the support provided by teachers during the teaching-learning process, when it came to promoting and maintaining motivation among the students. They stated that the teachers had created a climate of open and positive relationship for a learning environment, and answered questions about the content, learning activities, evaluation activities and technical problems. In addition, teachers guided them in the planning and organization of personal study, as well as team work, and they found acceptable the support given to them in the use of the tools/virtual spaces: e-mail, chat, forum, video conferencing, Internet, databases, as well as in the search for new resources, and new sources of information. In the comments section, students stressed that there is a lack of 
communication between teacher-student and that better methods of evaluation should be implemented. In accordance with Lopez-Cervantes (2014) good teachers question their educational practice to enrich their task, through a variety of teaching, learning, and communication strategies. Therefore, it is recommended that the teacher should have methodological elements, attitude, and aptitude.

\section{Organization Variable:-}

About the tools/communication spaces that the UACH provides to students during their formative process (e-mail, Moodle, forums, chats), students indicated that all were used. Face-to-face modality students stated that email was the most used, while students of blended and virtual modalities used forums the most. This result indicates that it is necessary to promote the use of these tools in order to exchange information on the course content or assigned tasks, and not only for personal or private issues.

\section{Difficulty during the Educational Process:-}

In terms of conflicts during the educational process, students considered a low degree of difficulty to access the platform (technological environment), navigate through the spaces, and download course materials. They had no problem understanding how to carry out the learning activities requested in the course, and the difficulty to understand the content of the course and carry out the integration activities, was considered low. They know, without a doubt, the delivery dates of the tasks or activities, as well as the assessment criteria. The communication with the professor-tutor and their peers via e-mail and forum participation is not a problem for students.

\section{Satisfaction of the TyMI Online Course Educational Process:-}

For students who are enrolled in or have completed the TyMI course, the degree of satisfaction was acceptable, as they considered the quality and relevance of the contents, learning activities used in the course, type of material or resources used, inclusive activities, course technological platform, and teacher's help, as acceptable. The course didn't obtain a high or very high degree of satisfaction, which indicates that approval mechanisms, periodic program review and monitoring, as well as materials and learning activities, must be implemented. It is necessary to develop and review said materials on a regular basis, thus ensuring their importance and permanent relevance.

\section{Correlation and Regression Analysis:-}

The analysis showed a significant positive correlation between the student's satisfaction regarding the independent variables, while regression analysis resulted in the following equation:

$$
\begin{gathered}
\mathrm{SC}=1.252+0.134(\mathrm{X} 1)+0.016(\mathrm{X} 2)+0.576(\mathrm{X} 3)+0.227(\mathrm{X} 4)+0.224(\mathrm{X} 5)--0.01(\mathrm{X} 6) . \\
\text { Where: } \mathrm{SC}=\text { Student's Course satisfaction }
\end{gathered}
$$

The intercept (1.252) is a result of the participant's previous knowledge; that is, the experience students already have in ICT use. The researchers García et al. (2007) mention that digital natives are students under 30 years old, who have grown up on par with technology, which allows them to have innate abilities in digital environments. Said students depend on technological tools for all kinds of daily tasks, such as studying, forming bonds, shopping, being informed, or even have fun. This reality implies that the great challenge teachers of all levels must face every day, is related to the way in which ICTs can support the teaching-learning process. It's about creating a learning environment based on the use of ICTs, which requires a great effort in terms of pedagogical design, as well as in the selection of pertinent technological tools that will encourage students to appropriate knowledge.

The maximum score resulting from the regression equation $(1.252+0.67+0.08+2.88+1.135+1.12-0.05=7.087)$ wasn't the one anticipated. Nevertheless, it could be improved with the actualization of course contents, as well as with an increment in quantity and quality of the support provided by the teacher to the students in terms of technical problem resolution. In contrast, the minimum score $(1.252+0.134+0.016+0.576+0.227+0.224-0.01=2.419)$ can be improved by diminishing the difficulty level during the educational process. For example, reducing difficulties such as access to the platform, clearing up evaluation criteria, downloading digital materials, among others. It would also be important to increase communication through the various communication tools/spaces provided by the university during the educational process.

\section{Discussion:-}

The student comments that had a bigger impact in the TyMI course, were that the class needed to be more dynamic and innovative; that activities should be interactive, different, fun and simple, with educational and comprehensive 
aims, as well as team oriented and practical. Some of the participants mentioned that the course should include: different themes, updated material, more headings or checklists, increased clarification of doubts, company and exhibition visits, as well as an analysis of the activities. They also mentioned that the platform was inadequate, the computer equipment should be changed, and the level of difficulty in the activities should be increased, as well as the depth of the information search topic. More tutorials, team work, practical lessons related to their major, better evaluation methods, and more didactic classes were also mentioned, adding to the list increased teacher-student communication, extra counseling classes, better activities' programming, trained teachers, changes to the program and unnecessary material. They also noted that there were frequent failures in the platform, that there should be increased attention to students, fewer class hours, less work, more readings, that the course should be removed, perform self-evaluations, reduce sizes, that there was respect among teachers and students, excellent teachers, but also missing teachers. Approximately $20 \%$ of the participants commented that all was well.

It is clear that learning environments should be planned to create pedagogical and contextual conditions where knowledge and their relations with the individuals are the main factor to form a "knowledge society".

To innovate in learning, planning should consider its various components: counselors, tutors, students, the contents and their treatment or didactic methodology, and technology. Although it is important to know how to search for and locate information banks that enrich and support learning processes, it is necessary to rethink the ways in which students can acquire knowledge and information without losing sight of the fact that in every situation, teaching the student shall be the center of attention. The role of the teacher will be that of a facilitator who provides assistance when the student seeks knowledge. It's all about new schemes where the information and communication technologies, with the support of telecommunications, become a basic instrument of every day intellectual work.

It is important to mention that interactivity enables the development of communication processes and fosters exchange among the participants, removing some time and space barriers. For example, in educational programs the computers fulfill three main functions: the traditional role as a tool for students to acquire a minimum level of computer knowledge; to support and complement curricular content; and as a means of interaction between teachers and students. The incorporation of media, therefore, forces users to have a technological literacy which is achieved by having access to readings and ideas related to the use of the technology, thus acquiring a broad technological reference frame. It is important for the student and the teacher to feel confident in their ability to take ownership of said technology.

\section{Conclusions:-}

It is concluded that the majority of the students feel good about the TyMI course and that there is a good mastery of ICTs on the students' behalf. However, there are several aspects that must be changed in order to make it a more interactive and innovative course, according to current needs. It is recommended that these results are used as basis for an informative and formative proposal; to aid in the preparation of the teacher, both in teaching and in the technological sense; and to update some of the course material topics with innovative content which promotes the student's interests in a teaching-learning process more meaningful and relevant to the reality in the classroom and the needs of their environment. In other words, it is recommended that these results be the basis for a program proposal where the central axes are the powers of information and communication technologies necessary for meaningful learning, and consistent with the area of specialty of each university student. Finally, it would be coherent to give training courses to teachers, both in technology and in pedagogy, as well as to update computer equipment and improve the platform.

\section{Reference:-}

1. Campo Saavedra, María Fernanda, Roxana Segovia de Cabrales, Patricia del Pilar Martínez Barrios, Hector Jaime Rendón Osorio and Gina Graciela Calderón Rodríguez (2013), "Competencias TIC para el Desarrollo Profesional Docente", Colección Sistema Nacional de Innovación Educativa con uso de Nuevas Tecnologías, First Edition - Independent Work, ISBN: 978-958-750-762-1, Printed by: Imprenta Nacional, at: http://www.colombiaaprende.edu.co/html/micrositios/1752/articles-318264_recurso_tic.pdf (consulted: 25th August, 2015).

2. Castro, Santiago, Guzmán, Belkys, Casado, Dayanara (2007), "Las Tic en los procesos de enseñanza y aprendizaje", Laurus, vol. 13, núm. 23, pp. 213-234, at: 〈http://www.redalyc.org/articulo.oa?id=76102311> ISSN 1315-883X (consulted: 3rd June, 2016). 
3. Díaz Alcántara, Óscar (2010), "Formación tecnopedagógica: DIY para tecnófobos", Apertura: Revista De Innovación Educativa, vol. 2, num. 2, pp. 108-121.

4. Espinoza, Norelkys, Ángel Gabriel, Rincón, y Belkys Chacín (2006), "Búsqueda de información en la Web por profesionales de salud en una universidad venezolana. Un estudio transversal", El Profesional de la Información, vol. 15, num. 1, pp. 28-33.

5. García Cabrero, Benilde y Vania Jocelyn Pineda Ortega (2010), "La construcción de conocimiento en foros virtuales de discusión entre pares", Revista Mexicana De Investigación Educativa, vol. 15, num. 44, pp. 85-111.

6. García, Felipe, Javier Portillo, Jesús Romo y Manuel Benito (2007), "Nativos digitales y modelos de aprendizaje", paper presented at the "IV Simposio Pluridisciplinar sobre Diseño, Evaluación y Desarrollo de Contenidos Educativos Reutilizables", Bilbao, Spain, Septiember 2007, at: http://ceur-ws.org/Vol318/Garcia.pdf (consulted: 22nd Osctober, 2015).

7. Hattie, John y Helen Timperley (2007), "The power of feedback", Review of Educational Research, vol. 77, num. 1, pp. 81-112.

8. Huett, Kim y Barbara Kawulich (2015), "A Qualitative Evaluation of the Use of Multimedia Case Studies in an Introductory Engineering Course at Two Southeastern Universities", Journal of STEM Education: Innovations \& Research, vol. 16, num, 3, pp. 34-39.

9. López Cervantes, Guillermo, Norberto Sotelo Cruz, Guillermo Hernández Chávez y Alfredo Padilla Barba (2014), "Percepción del Alumno al Curso de Anatomía Humana en Medicina, una Experiencia Vivencial", Boletín Clínico Hospital Infantil del Estado de Sonora, vol. 31, num. 2, pp. 111-115.

10. Marín Uribe, Rigoberto (2006), El modelo educativo de la UACH: elementos para su construcción. ISBN: 968 6331-99-9, Chihuahua, México, Universidad Autónoma de Chihuahua.

11. Moodle (2015), "AboutMoodle" at: https://docs.moodle.org/31/en/About_Moodle (consulted: 18th September 2015).

12. Olivares Olivares, Silvia Lizett y Yolanda Heredia Escorza (2012), "Desarrollo del pensamiento crítico en ambientes de aprendizaje basado en problemas en estudiantes de educación superior", Revista Mexicana De Investigación Educativa, vol. 17, num. 54, pp. 759-778.

13. Rodríguez Albor, Gustavo, Viviana Gómez Lorduy y Marco Ariza Dau (2014), "Calidad de la educación superior a distancia y virtual: Un análisis de desempeño académico en Colombia", Investigación y Desarrollo, vol. 22, num. 1, pp. 79-119.

14. UNESCO (1998), "La educación superior en el siglo XXI: Visión y acción", París, Francia, at: http://www.Unesco.org/education/educprog/wche/declaration_spa.htm, (consulted: 25th August, 2015). 